Tropical Journal of Pharmaceutical Research March 2019; 18 (3): 639-645

ISSN: 1596-5996 (print); 1596-9827 (electronic)

(C) Pharmacotherapy Group, Faculty of Pharmacy, University of Benin, Benin City, 300001 Nigeria.

\title{
Meta-analysis of effectiveness of traditional Chinese medicine or its combination with Western medicine in the treatment of triple negative breast cancer
}

\author{
Wang Yukun ${ }^{1}$, Yao Chang ${ }^{2}$, He Fan ${ }^{3}$, Zeng Jiayao ${ }^{1 *}$ \\ ${ }^{1}$ Department of Thyroid and Breast Surgery, The First Affiliated Hospital of Guangxi University of Traditional Chinese Medicine, \\ Nanning, Guangxi 530023, ${ }^{2}$ Department of Breast Surgery, Jiangsu Province Traditional Chinese Medicine Hospital, Nanjing, \\ Jiangsu 210029, ${ }^{3}$ Department of General Surgery, Jiashan First People's Hospital, Jiashan, Zhejiang 314100, China
}

*For correspondence: Email: nl1196@163.com

Sent for review: 8 December 2018

Revised accepted: 28 February 2019

\begin{abstract}
Purpose: To assess the efficacy and side effects of Traditional Chinese Medicine (TCM) in the management of triple negative breast cancer (TNBC).

Methods: Full text data on randomized controlled trial (RCT) of TNBC treated with TCM or its combination with Western Medicine (WM) were retrieved from the Chinese biomedical literature database, Chinese periodicals, Chinese Science-Technology periodicals and VP and PubMed. The qualities of the RCTs were evaluated. Revman 5.3 was used to conduct the meta-analysis.

Results: A total of 16 RCTs involving 1186 patients were included. Analysis of these RCTs showed significant differences in total effectiveness between WM and TCM or combination of TCM with WM $\{(O R=2.63,95 \% \mathrm{Cl}=1.37,5.03)$, test of the combined effect $(Z=2.91, p<0.005)\}$.

Conclusion: The results show that TCM is effective in the treatment TNBC.
\end{abstract}

Keywords: Triple negative breast cancer, Chinese medicine therapy, Meta-analysis, Randomized controlled trial

\begin{abstract}
This is an Open Access article that uses a funding model which does not charge readers or their institutions for access and distributed under the terms of the Creative Commons Attribution License (http://creativecommons.org/licenses/by/4.0) and the Budapest Open Access Initiative (http://www.budapestopenaccessinitiative.org/read), which permit unrestricted use, distribution, and reproduction in any medium, provided the original work is properly credited.
\end{abstract}

Tropical Journal of Pharmaceutical Research is indexed by Science Citation Index (SciSearch), Scopus, International Pharmaceutical Abstract, Chemical Abstracts, Embase, Index Copernicus, EBSCO, African Index Medicus, JournalSeek, Journal Citation Reports/Science Edition, Directory of Open Access Journals (DOAJ), African Journal Online, Bioline International, Open-J-Gate and Pharmacy Abstracts

\section{INTRODUCTION}

Negative-expressions of human-epidermalgrowth-factor-receptor-2 (Her-2), progesterone receptor (PR), and estrogen receptor (ER) are characteristic features of TNBC, a malignant tumor with strong invasiveness and poor prognosis [1]. The current treatments for TNBC involve the use of chemotherapy, radiation therapy, molecular targeted therapy and Chinese medicine [2]. The prognosis of WM treatment is worse for TNBC than general breast cancer, due to more severe adverse reactions. In contrast, TCM achieves better results which have been recognized by many scholars. Thus, studies on TCM and integration of TCM and WM for the treatment of TNBC are increasing year after year. However, the universality of the safety and efficacy of TCM have not been investigated. Furthermore, it is necessary to systematically evaluate existing evidence with respect to its safety and universality using quantitative indicators. The current study focused on 
systematic analysis of effectiveness of only TCM or in combination with WM to treat TNBC.

\section{METHODS}

\section{Participants}

These included patients were diagnosed with triple-negative breast cancer by postoperative pathological diagnosis, imaging examination and hormone receptor examination and randomized controlled trials (RCTs) involving treatment with TCM or integration of TCM and WM, blinded or un-blinded.

The Ethical Committee of Department of General Surgery, Jiashan First People's Hospital, Jiashan, Zhejiang, China, approved this study (approval no. 201811725), which was conducted based on the Helsinki Declaration [3].

\section{Inclusion criteria}

\section{Diagnostic criteria}

These included postoperative pathological examination resulting in diagnosis of breast cancer, and immunohistochemistry showing negative expressions of ER, PR and HER-2.

\section{Intervention}

Studies involving treatment with TCM or combination of TCM and WM in which the TCM was given through oral administration, external application and emotional therapy, and (b) studies in which the control group used WM treatment methods such as surgery, WM, and radiotherapy, and combination treatment studies involving use of both TCM and strategies, were included.

\section{Study indices}

Studies in which clinical remission was evaluated according to WHO evaluation criteria; studies in which total effectiveness was evaluated as the sum of complete responses and partial responses, with secondary observation indicators such as quality of life, immune indicators and survival rates, were included.

\section{Exclusion criteria}

The excluded studies were: non-RCT literature, randomized controlled trials involving different Chinese medicine or integrated TCM and WM treatment regimens in the control-group and the treatment-group, non-clinical studies, studies without clinical observation, studies involving animal experiments, reviews, and clinical studies without statistical analysis.

\section{Literature search}

The search database included China Journal Full-text Database "China National Knowledge Internet (CNKI)", Chinese Science and Technology Periodical Database (VIP), China Biomedical Literature Database (CBM), PubMed and Wanfang. The search terms included: TNBC, TCM, WM, Chinese Herbal Drug, etc.

\section{Data extraction and quality assessment}

Cochrane System Evaluator's Handbook (version 5.1.0) was combined with the Jadad 3 item 5point method for evaluation of the qualities of the included researches [4]. The scoring-criteria was like the following: double-blinded and appropriate double-blinded method description were scored one point; description of appropriate randomized method was scored one point; and description of follow-up and withdrawal status was scored one point. Publication quality was scored low (0 to 2 points), or high (3 to 5 points). Two evaluators worked independently to evaluate the publications in line with the above criteria. If there are disagreements between the two assessors, they were resolved through a third party.

\section{Statistical analysis}

RevMan 5.3 statistical software (Cochrane) was used. Heterogeneity test was carried out with $x^{2}$ test $\left(\alpha=0.01, \mathrm{I}^{2}=50 \%\right)$. Heterogeneity was indicated when $p \geq 0.1$ and $I^{2} \leq 50 \%$, and the fixed effect model was used for meta-analysis. On the other hand, if $\mathrm{I}^{2} \geq 50 \%$ and $p<0.1$, the random-effect-model (REM) would be adopted. The representation of the count data was based on an estimate of relative risk (OR) and its $95 \%$ $\mathrm{Cl}$.

\section{RESULTS}

The search results were screened from 1193 relevant studies according to inclusion criteria and exclusion criteria, and 16 studies were finally included. These involved a total of 1186 patients, as shown in Table 1.

\section{Meta-analysis results}

Total effectiveness referred to the sum of partial remission and complete remission. Eight studies (542 patients) reported remission of TNBC treated with TCM or combination of traditional Chinese and WM, relative to WM. The results of meta-analysis revealed that heterogeneity test $p$ 
Table 1: Basic characteristics of, and Jadad scores for the research works

\begin{tabular}{|c|c|c|c|c|c|c|c|}
\hline Author & $\begin{array}{l}\text { Stochastic } \\
\text { method }\end{array}$ & $\begin{array}{l}\text { Blind } \\
\text { method }\end{array}$ & $\begin{array}{l}\text { Exit lost } \\
\text { visit }\end{array}$ & $\begin{array}{l}\text { Jadad } \\
\text { score }\end{array}$ & $\begin{array}{c}\text { Intervention } \\
\text { (treatment/control) }\end{array}$ & $\begin{array}{c}\text { Total number of } \\
\text { cases } \\
\text { (trial/control) }\end{array}$ & $\begin{array}{c}\text { Year of } \\
\text { publication }\end{array}$ \\
\hline $\begin{array}{c}\text { Xu Chuan } \\
{[5]}\end{array}$ & Random & $\begin{array}{l}\text { Not } \\
\text { stated }\end{array}$ & $\begin{array}{l}\text { No loss to } \\
\text { follow-up }\end{array}$ & $\begin{array}{c}2 \\
\text { points }\end{array}$ & $\begin{array}{l}\text { Radiotherapy and } \\
\text { Chemotherapy+Ruyanning } \\
\text { Prescription/Radiotherapy } \\
\text { and Chemotherapy }\end{array}$ & $60(30 / 30)$ & 2015 \\
\hline $\begin{array}{l}\text { Chen } \mathrm{Yu} \\
{[6]}\end{array}$ & $\begin{array}{l}\text { Random } \\
\text { number } \\
\text { method }\end{array}$ & $\begin{array}{l}\text { Not } \\
\text { stated }\end{array}$ & $\begin{array}{l}\text { No loss to } \\
\text { follow-up }\end{array}$ & $\begin{array}{l}3 \\
\text { points }\end{array}$ & $\begin{array}{c}\text { Traditional Chinese Medicine } \\
\text { Treatment/Western Medicine } \\
\text { Treatment }\end{array}$ & $98(50 / 48)$ & 2015 \\
\hline $\begin{array}{l}\text { Zhang } \\
\text { Qiang [7] }\end{array}$ & $\begin{array}{l}\text { Random } \\
\text { number } \\
\text { method }\end{array}$ & $\begin{array}{l}\text { Not } \\
\text { stated }\end{array}$ & Not stated & $\begin{array}{c}2 \\
\text { points }\end{array}$ & $\begin{array}{c}\text { Shenqi Fuzheng } \\
\text { Liquid+/Western Medicine } \\
\text { Treatment }\end{array}$ & $100(50 / 50)$ & 2013 \\
\hline $\begin{array}{c}\text { Lu } \\
\text { Yuanzhong } \\
{[8]}\end{array}$ & random & $\begin{array}{l}\text { Not } \\
\text { stated }\end{array}$ & $\begin{array}{l}\text { No loss to } \\
\text { follow-up }\end{array}$ & $\begin{array}{c}2 \\
\text { points }\end{array}$ & $\begin{array}{l}\text { Tribulus terrestris Bushen } \\
\text { Mixture/Chemotherapy }\end{array}$ & $100(50 / 50)$ & 2010 \\
\hline $\begin{array}{l}\text { Zhu Jing } \\
{[9]}\end{array}$ & Random & $\begin{array}{l}\text { Not } \\
\text { stated }\end{array}$ & $\begin{array}{l}\text { No loss to } \\
\text { follow-up }\end{array}$ & $\begin{array}{c}2 \\
\text { points }\end{array}$ & $\begin{array}{c}\text { Xiaoyao } \\
\text { Sanjiao+Capecitabine/Capec } \\
\text { itabine }\end{array}$ & $56(32 / 24)$ & 2014 \\
\hline Xiao Li [10] & Random & $\begin{array}{l}\text { Not } \\
\text { stated }\end{array}$ & Not stated & 1 point & $\begin{array}{c}\text { Shenyi } \\
\text { Capsule+Capecitabine/Cape } \\
\text { citabine }\end{array}$ & $30(15 / 15)$ & 2014 \\
\hline $\begin{array}{l}\text { Lv Xiaoai } \\
\quad[11]\end{array}$ & $\begin{array}{l}\text { Random } \\
\text { number } \\
\text { method }\end{array}$ & $\begin{array}{l}\text { Not } \\
\text { stated }\end{array}$ & Not stated & $\begin{array}{c}2 \\
\text { points }\end{array}$ & $\begin{array}{c}\text { Sanye } \\
\text { Qingsan+Chemotherapy/Che } \\
\text { motherapy }\end{array}$ & $107(55 / 52)$ & 2014 \\
\hline $\begin{array}{l}\text { Cui } \\
\text { Honghai } \\
\text { [12] }\end{array}$ & random & $\begin{array}{l}\text { Not } \\
\text { stated }\end{array}$ & Not stated & $\begin{array}{c}1 \\
\text { points }\end{array}$ & $\begin{array}{l}\text { Shugan Jianpi Jiedu } \\
\text { Powder+Chemotherapy/Che } \\
\text { motherapy }\end{array}$ & $60(30 / 30)$ & 2015 \\
\hline $\begin{array}{l}\text { Wang } \\
\text { Zhiguang } \\
\text { [13] }\end{array}$ & $\begin{array}{l}\text { Random } \\
\text { number } \\
\text { method }\end{array}$ & $\begin{array}{l}\text { Not } \\
\text { stated }\end{array}$ & $\begin{array}{l}1 \text { case lost } \\
\text { to follow } \\
\text { up }\end{array}$ & $\begin{array}{c}3 \\
\text { points }\end{array}$ & $\begin{array}{c}\text { Shugan Jianpi Yishen } \\
\text { Traditional Chinese } \\
\text { Medicine+Chemotherapy/Ch } \\
\text { emotherapy }\end{array}$ & $60(30 / 30)$ & 2015 \\
\hline $\begin{array}{c}\text { Ren } \\
\text { Xiaoyin } \\
\text { [14] }\end{array}$ & random & $\begin{array}{l}\text { Not } \\
\text { stated }\end{array}$ & Not stated & 1 point & $\begin{array}{c}\text { Traditional Chinese Medicine } \\
\text { for Soothing Liver, } \\
\text { Strengthening Spleen and } \\
\text { Benefiting Kidney+GT } \\
\text { Chemotherapy }\end{array}$ & $50(25 / 25)$ & 2015 \\
\hline $\begin{array}{l}\text { Tang Rui } \\
\text { [15] }\end{array}$ & Random & $\begin{array}{c}\text { Not } \\
\text { stated }\end{array}$ & $\begin{array}{l}\text { No loss to } \\
\text { follow-up }\end{array}$ & $\begin{array}{c}2 \\
\text { points }\end{array}$ & $\begin{array}{c}\text { Yiqi Rehabilitation } \\
\text { Prescription+Western } \\
\text { Medicine } \\
\text { Treatment/Western } \\
\text { Medicine Treatment }\end{array}$ & $59(30 / 29)$ & 2016 \\
\hline $\begin{array}{l}\text { Li Yang } \\
\quad[16]\end{array}$ & $\begin{array}{l}\text { Random } \\
\text { number } \\
\text { method }\end{array}$ & $\begin{array}{c}\text { Not } \\
\text { stated }\end{array}$ & Not stated & $\begin{array}{c}2 \\
\text { points }\end{array}$ & $\begin{array}{c}\text { Traditional Chinese } \\
\text { Medicine Emotional Therapy } \\
\text { + Western Medicine } \\
\text { Therapy/Western Medicine } \\
\text { Therapy }\end{array}$ & $90(45 / 45)$ & 2015 \\
\hline $\begin{array}{c}\text { Zheng } \\
\text { Guilan [17] }\end{array}$ & $\begin{array}{l}\text { Random } \\
\text { number } \\
\text { method }\end{array}$ & $\begin{array}{c}\text { Not } \\
\text { stated }\end{array}$ & $\begin{array}{l}2 \text { cases of } \\
\text { withdrawal }\end{array}$ & $\begin{array}{c}3 \\
\text { points }\end{array}$ & $\begin{array}{c}\text { Refining and Kidney- } \\
\text { tonifying } \\
\text { Prescription+Chemotherapy/ } \\
\text { Chemotherapy }\end{array}$ & $60(30 / 30)$ & 2010 \\
\hline $\begin{array}{l}\text { Chen Hai } \\
\text { [18] }\end{array}$ & $\begin{array}{l}\text { Random } \\
\text { number } \\
\text { method }\end{array}$ & $\begin{array}{c}\text { Not } \\
\text { stated }\end{array}$ & $\begin{array}{l}\text { No loss to } \\
\text { follow-up }\end{array}$ & $\begin{array}{c}3 \\
\text { points }\end{array}$ & $\begin{array}{c}\text { Traditional Chinese } \\
\text { Medicine+Western Medicine } \\
\text { Treatment/Western } \\
\text { Medicine Treatment }\end{array}$ & $98(50 / 48)$ & 2014 \\
\hline $\begin{array}{c}\text { Huang } \\
\text { Xiying [19] }\end{array}$ & $\begin{array}{l}\text { Random } \\
\text { number } \\
\text { method }\end{array}$ & $\begin{array}{c}\text { Not } \\
\text { stated }\end{array}$ & Not stated & $\begin{array}{c}2 \\
\text { points }\end{array}$ & $\begin{array}{c}\text { Shuijin Capsule+Western } \\
\text { Medicine } \\
\text { Treatment/Western } \\
\text { Medicine Treatment }\end{array}$ & $60(30 / 30)$ & 2011 \\
\hline $\begin{array}{c}\text { Chen Zhijia } \\
\text { [20] }\end{array}$ & $\begin{array}{l}\text { Random } \\
\text { number } \\
\text { method }\end{array}$ & $\begin{array}{c}\text { Not } \\
\text { stated }\end{array}$ & Not stated & $\begin{array}{c}2 \\
\text { points }\end{array}$ & $\begin{array}{c}\text { Traditional Chinese } \\
\text { Medicine Compound } \\
\text { Formula+Chemotherapy/Ch } \\
\text { emotherapy }\end{array}$ & $98(50 / 48)$ & 2015 \\
\hline
\end{tabular}




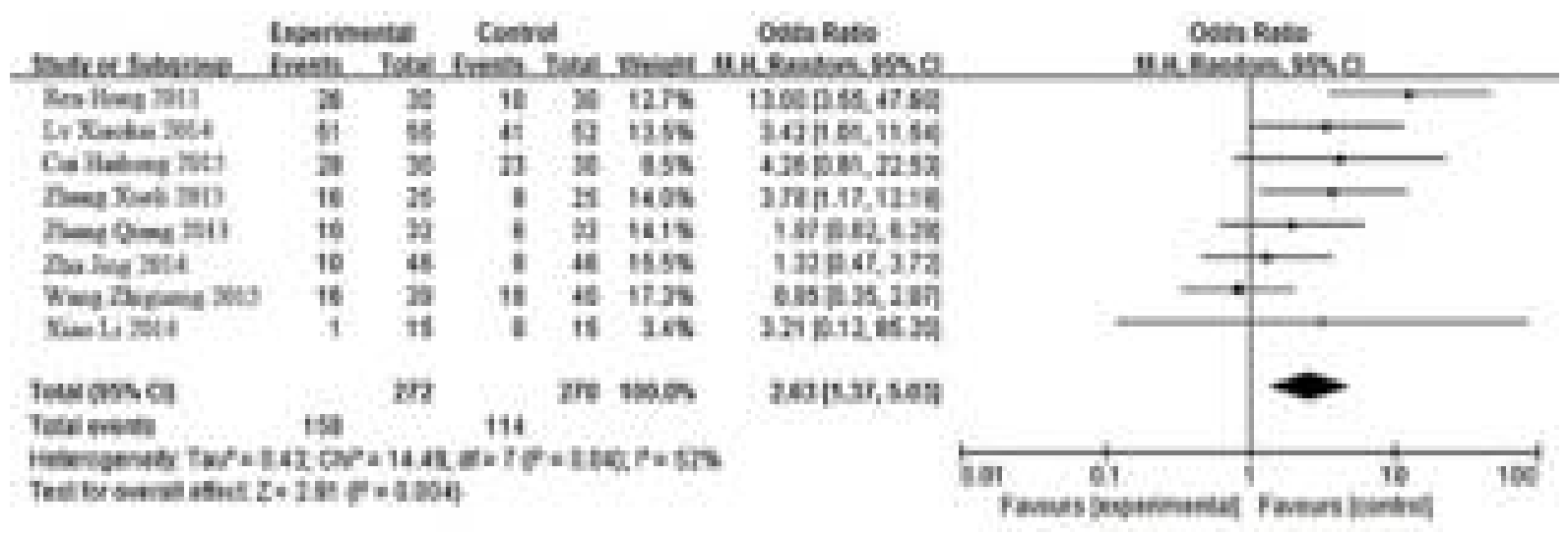

Figure 1: Total effectiveness in TCM, integrated TCM and WM, and WM groups

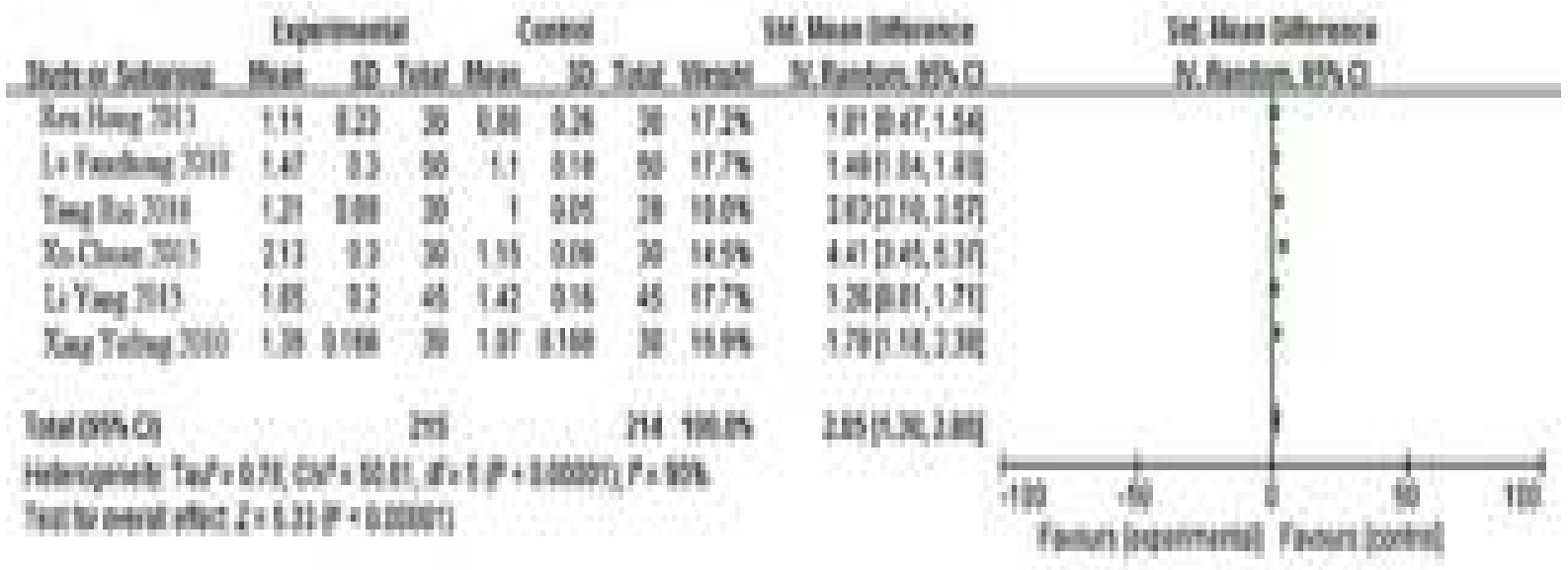

Figure 2: CD4/CD8 in the treatment of TNBC with TCM or TCM-WM combination, and WM

was 0.004 (i.e. below 0.1). Thus, REM was adopted. The combined effect $O R$ value was 2.63, with $95 \% \mathrm{Cl}=1.37,5.03$. The combined effect $Z$ value was 2.91 ( $p<0.005$ ), indicating a significant difference between the experimentalgroup and the control-group. The curative-effects in experimental-group were better than those in control-group. These results are shown in Figure 1.

\section{Immune function}

Six of the 16 studies used CD4/CD8 T cell ratio as the effect index in 429 patients (215 cases received $\mathrm{TCM}$ or integrated $\mathrm{TCM}$ and $\mathrm{WMs}$, while 214 cases received WM in the controlgroup). The heterogeneity test $p<0.00001$. Thus, REM was adopted, and the combined effect-size was SMD $(95 \% \mathrm{Cl}=1.30,2.80 ; \mathrm{Z}=$ 5.33; $p<0.00001)$, indicating that the CD4/CD8 ratios in TCM or integrated TCM and WM group were higher than those in WM control-group after treatment (Figure 2).

\section{Quality of life}

Six out of the 16 studies described evaluation of the quality of life, and the KPS life status score was used as the observation index. However, one comparison was reflected in the form of mean variance, so it was not included. Totally, 339 patients were enrolled finally, comprising 170 treated with TCM or integrated TCM and WM, and 169 patients in the control group treated with WM. In heterogeneity-test, $p<$ 0.00001 , thus REM was used. Combined OR value is 3.66; $95 \% \mathrm{Cl}=2.07,6.48 ; \mathrm{Z}=4.45 ; p<$ 0.00001 , indicating that the life qualities associated with TCM or integrated TCM and WMs were better than those seen in WM control group. These results are shown in Figure 3.

\section{Survival rate}

Four out of the 16 studies reported survival rate, and involved a total of 394 patients, 200 of whom were treated with TCM or TCM-WM combinations, while 194 patients received WM (control group). In heterogeneity-test, $p<0.0001$. Thus, the REM was used. The pulled $\mathrm{OR}=6.89$; $95 \% \mathrm{Cl}=2.81,16.87$; the combined effect test $p$ $=0.00014 .22$, indicating that the survival rate of patients treated with TCM or TCM plus WM was 


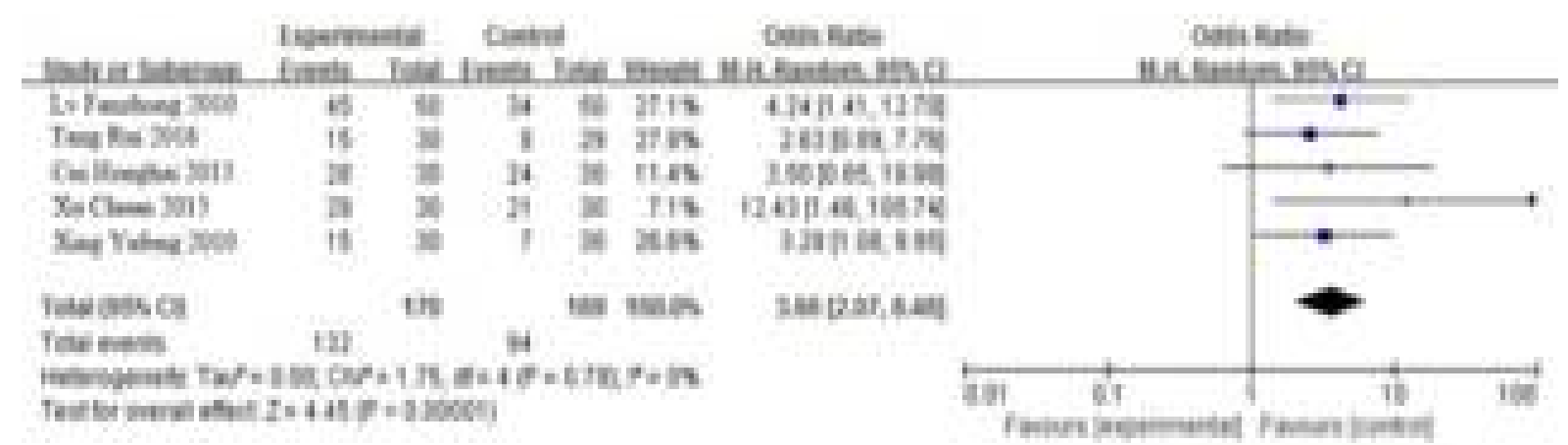

Figure 3: Quality of life in TNBC patients treated with TCM or Chinese-Western combination, and WM

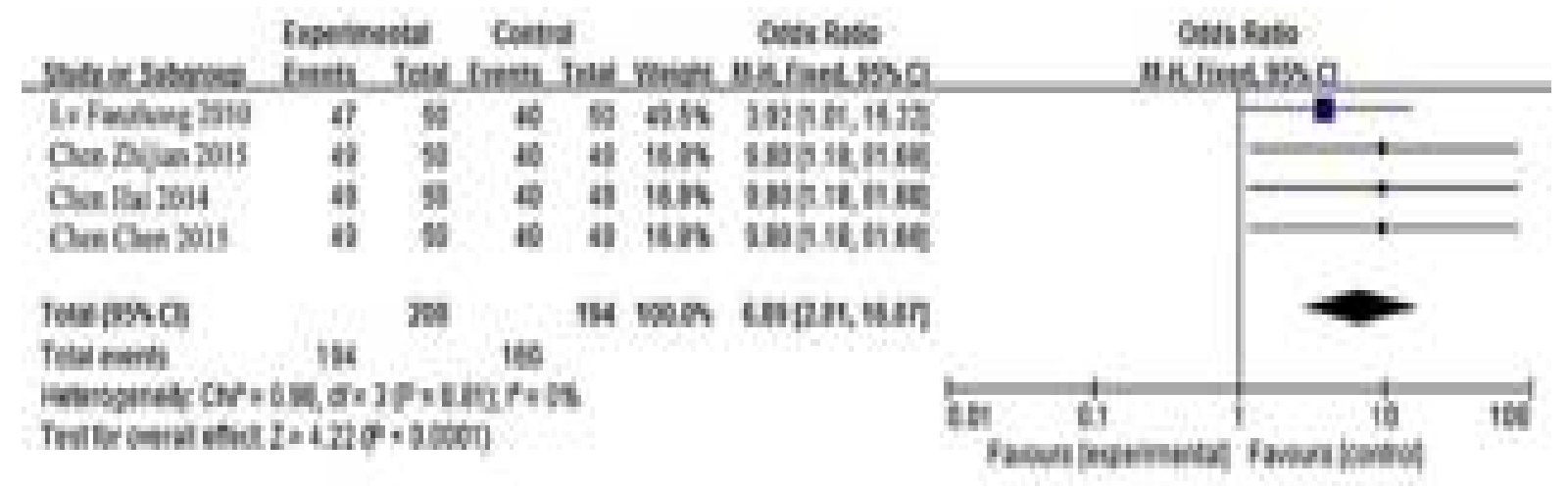

Figure 4: Survival rate of TNBC patients treated with TCM or TCM plus WM, and WM

better than that of those treated with WM (Figure 4).

\section{Publication bias}

Meta-analysis of selected literature may be subject to publication bias to a large extent. In practice, the existence or absence of publication bias can often be judged by the use of the funnel plot. The OR value of the comprehensive effect in the included study is the abscissa and the reciprocal of the OR standard error is the ordinate. In this study, the funnel chart was drawn using statistical analysis software (Figure 5). It can be seen that there was no obvious publication bias.

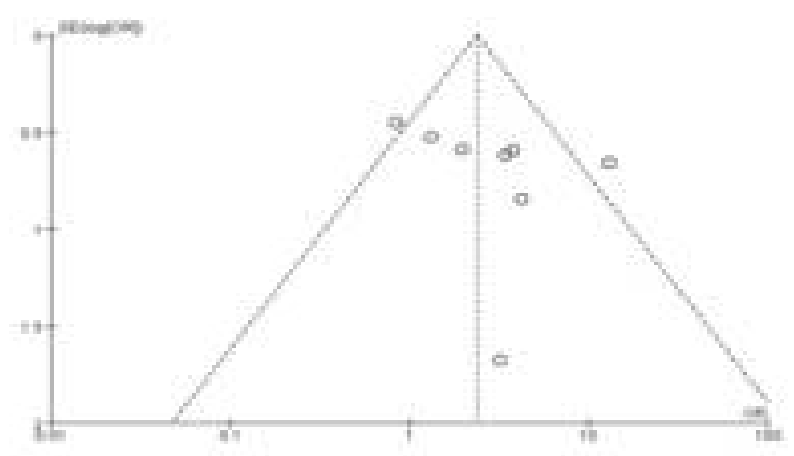

Figure 5: Funnel plot for publication bias

\section{DISCUSSION}

TNBC is with a high recurrence rate, easy metastases and poor prognosis $[21,22]$. Although a large number of clinical trials have been conducted, no targeted treatment regimens have been identified. Triple-negative breast cancer is categorized in TCM as "Shijie" and "lactstone". TCM is usually applied according to the etiology and pathogenesis of TNBC. Individualized treatment plans are used for the specific conditions of each patient. Moreover, Chinese medicine is used in combination with WM to treat TNBC. In the present study, the meta-analysis included 16 articles involving a total of 1186 subjects. After analyzing the effect indicators such as total effectiveness, CD4/CD8T ratio, quality of life and survival rate, it was found that the difference is obvious between the group with TCM/integrated TCM and WM, and the group given WM only. Moreover, no serious adverse reactions were associated with combined treatment with TCM and WM, or TCM alone. This indicates that TCM or TCM plus WM has certain advantages over WM to treat TNBC. These advantages include reduction in the side effects of radiotherapy and chemotherapy, improvement in the quality of life of patients, recurrence of antitumor metastasis, and higher survival rate. Thus, the combined treatment is a new and beneficial strategy for clinical treatment of TNBC. 
Heterogeneity test showed that there was high heterogeneity between the studies. This may be related to the intervention, experimental design and quality of the studies used. Most of the literature mentioned only random grouping, but did not use blinding method. This may also be responsible for observed heterogeneity. The study did not carry out further analysis to identify the sources of heterogeneity, thus REM was adopted. Low publication bias between the studies improved the reliability of the analysis results.

\section{CONCLUSION}

The results of the analyses carried out in this study show that TCM is effective in the treatment of TNBC. However, the efficacy of TCM or TCM plus WM for treating TNBC should be subjected to further studies. The present investigation reveals that most of the included articles had low Jadad scores, and the method of random grouping was not specifically described. Moreover, blinding was not specified and the losses to follow-up were not indicated in many instances. These lapses made it difficult to judge rationality of the experimental design and results. In addition, most of the included literature did not classify and reflect syndrome differentiation and treatment in Chinese medicine. Therefore, more large-scale, multi-center, completely randomized controlled clinical trials are needed to demonstrate the safety and effectiveness of TCM to treat TNBC.

\section{DECLARATIONS}

\section{Conflict of Interest}

No conflict of interest associated with this work.

\section{Contribution of Authors}

We declare that this work was done by the author(s) named in this article and all liabilities pertaining to claims relating to the content of this article will be borne by the authors, all authors read and approved the manuscript for publication. He Fan and Zeng Jiayao conceived and designed the study, Wang Yukun, Yao Chang, He Fan collected and analysed the data, Wang Yukun wrote the manuscript. He Fan and Zeng Jiayao are co-corresponding authors.

\section{REFERENCES}

1. Costa $R$, Shah $A N$, Santa-Maria $C A$, Cruz MR, Mahalingam D, Carneiro $B A$, Chae $Y K$, Cristofanilli $M$,
Gradishar WJ, Giles FJ. Targeting Epidermal Growth Factor Receptor in triple negative breast cancer: New discoveries and practical insights for drug development. Cancer Treat Rev 2017; 53: 111-119.

2. Li KX, Zhou M, Qiang $Q$, Sun $X Y$, Wang $X M$. Research progress of triple negative breast cancer and treatment of traditional Chinese medicine. Hubei J Tradit Chin Med 2015; (03): 76-78.

3. World Health Organization. Declaration of Helsinki. Br Med J 1996; 313(7070): 1448-1449.

4. Zhao J, Du JH, Wang GL, Gao YJ, Yi QS, Wang BY. Meta-analysis of randomized controlled trials of traditional Chinese medicine in the treatment of essential hypertension. Chin J Tradit Chin Med 2018; (3): 922-926.

5. Xu C, Tong X, Yu XW, Li SL, Li M. Clinical study of Ruyan Ningfang in the treatment of triple negative breast cancer. Gansu Med J 2015; 34(11): 821-822.

6. Chen W, Liu H. Study on the Effect of Syndrome Differentiation of Traditional Chinese Medicine on Survival Rate of Patients with Sanyin Breast Cancer [J]. Shizhen Guo Yi Guo Yao, 2015(01): 156-157.

7. Zhang $Q$, Cai JB, Chen X, Shi WM, Yang LJ, Zhou J. Treatment of 32 cases of advanced triple-negative breast cancer with Shenqi Fuzheng injection combined with chemotherapy. Chin Pharm 2013; 16(12): 18661867.

8. Lv YZ, Kong QZ. Clinical study on the treatment of triplenegative breast cancer after operation with Qibu Shen Mixture. Hubei J Tradit Chin Med 2010; 32(6): 16-17.

9. Zhu J. Clinical study of Pitabine maintenance therapy combined with Xiaoyao Powder in the treatment of advanced triple-negative breast cancer. Hubei Univ Tradit Chin Med 2014; 24: 123-155.

10. Xiao L. Clinical efficacy of ginsenoside Rg3 combined with capecitabine in the treatment of advanced triplenegative breast cancer. Hebei Med 2015; (16): 24452447.

11. Lv XT, Wang W, Chen JB, Ye J. Pathological complete response rate of Sanye Qingsanjie anticancer prescription in patients with triple negative breast cancer treated with neoadjuvant chemotherapy. J Tradit Chin Med 2014; 55(23): 2016-2019.

12. Cui HH, Jiang SQ. Treatment of 30 Cases of Sanyin Breast Cancer with Shugan Jianpi Jiedu Sanjie Method. Henan J Tradit Chin Med 2015; 35(9): 2196-2198.

13. Wang ZG, Lin LZ. Efficacy and safety of Shugan Jianpi Yishen Chinese medicine combined with chemotherapy in the treatment of metastatic triple-negative breast cancer patients with liver stagnation. Chin J Gen Pract 2015; 18(6): 620-624.

14. Ren XY. Clinical analysis of traditional Chinese medicine combined with chemotherapy in the treatment of metastatic triple-negative breast cancer. Pract Chin Med J 2016; (11): 1096-1097.

15. Tang R, Zhao CY. Application of Yiqi Rehabilitation in the adjuvant treatment of triple-negative breast cancer and 
its effect on immune function. Sichuan $J$ Tradit Chin Med 2015; (12): 87-89.

16. Li $Y$, Huang $L Z$, Gong $H$, Zhang $H$, Xiao $Y J$, Wang $Y Q$, Liang H. Effect of TCM Emotional Therapy on Quality of Life in Patients with Triple Negative Breast Cancer during Postoperative Recovery. J Hunan Univ Tradit Chin Med 2015; 35(10): 54-56.

17. Zheng GL, Zhang JB, Li XH, Zhao Y, Li YJ, Li JZ. Comparative study on traditional Chinese medicine in postoperative triple negative breast cancer prevention and recurrence and metastasis. Mod Oncol Med 2017; 25(2): 220-223.

18. Chen H, Yan XL, Qiu P. Effect of Integrative Chinese and Western Medicine on Survival Rate of Patients with Sanyin Breast Cancer. Anhui Med J 2014; (9): 17571758.
19. Huang XY. Analysis of Immunity Function Changes of Chinese Medicine for Patients with Triple-negative Breast Cancer Treated with Radiation and Chemotherapy. J Mathematical Med 2016; 29(8): 11281129.

20. Chen ZJ. Effect of Chinese Herbs Treatment on Survival Rate of Three-negative Breast Cancer Patients. West $J$ Tradit Chin Med 2015; 28(9): 103-105.

21. Liang CL, Yang HJ. Research Progress on Neo-adjuvant Chemotherapy Medicine for Triple Negative Breast Cancer. J Chin Oncol 2018; 24(3): 188-194.

22. Ma J. Analysis of clinicopathological features and prognostic factors of triple negative breast cancer. For All Health 2017; 11(8): 22-23. 